\title{
Harvey Murine Sarcoma Virus
}

National Cancer Institute

\section{Source}

National Cancer Institute. Harvey Murine Sarcoma Virus. NCI Thesaurus. Code C28578.

A replication-defective mouse sarcoma virus first described by J.J. Harvey in 1964. The ras gene was first identified in this virus. 